Woodford County, Kentucky. Mr. May noticed that something had been running under a haystack, and, thinking it might be a mink, he set a trap under the stack and caught the mongoose,--an animal entirely strange to him and to other people of the vicinity. No record of how the mongoose reached the region can be traced.

This animal, Herpestes griseus, a native of India, is the same species which has been introduced into Cuba, Porto Rico, and several other places, for the destruction of noxious rodents, but it has become a serious pest on account of its destruction of poultry and birds. The capture of a single animal in the United States should not in itself unnecessarily alarm us, but it should stimulate us to be doubly on our guard. In spite of laws, ably administered and rigidly enforced, against importation or shipment of the mongoose in this country there is always a possibility that the animal might become established. Should such ever be the case it would spell the doom of all ground-nesting birds throughout a great part of the United States. Everybody interested in conservation of native wild-life should be able to recognize the mongoose and should report any occurrence of the animal in the country at once to the U. S. Biological Survey. The animal is really quite unlike any native North American species and is easily identified. It is a carnivore about the size of the mink and of similar proportions. The tail, however is rather longer than that of the mink, and tends to taper toward the tip. The animal is furred rather scantily, particularly ventrally, with a coarse, hispid hair. Its general tone of color is yellowish gray, distinctly flecked or grizzled with brownish black and whitish. This color effect is produced by an underfur of clay color intermixed with the longer guard hairs each one of which is banded alternately with fuscous-black and buffy white, the fuscous-black bands being the longer.-HARTLEY H. T. JACKSON, U. S. Biological Survey, Washington, D. C.

PRIBILOF FUR SEAL ON THE OREGON COAST

On February 1, 1921, an immature male Pribilof fur seal (Callorhinus alascanus Jordan and Clark) in a badly emaciated condition came ashore on the ocean beach about a mile north of the bar at Netarts Bay, Tillamook County, Oregon. When first seen by a loeal resident the seal was high up on the dry sand, above normal high tide, and was "quite active." About two hours later, when Mr. Clarence Edner of Netarts went to look for it, he found it lying dead in the wet sand just above the breakers. Mr. Edner thinks that after the animal was first seen it made an attempt to return to the sea but died before reaching the water.

So far as I am aware, this is the only authentic record in recent years of the occurrence of the Pribilof fur seal on the Oregon coast.-StanLery G. Jewatt, Portland, Oregon.

\title{
ELEPHANT SEALS OFF THE COAST OF CALIFORNIA
}

In the May number of the Journal of Mammalogy, page 112, there appeared an article by $A$. W. Anthony recording the appearance of elephant seals off the southwest coast of California. Several years ago Capt. Chas. Davis captured several young elephant seals on Guadalupe Island and brought them, alive, to

JOUHNAL OF MAMMALOGT, YOL, 2, NO. 1 
Venice, California, where they were exhibited in a tank of water for a year or two. The tank was on a pier extending out into the ocean.

A year or two ago a heavy storm demolished that portion of the pier where the seals were exhibited and they escaped into the ocean. It is quite probable that these animals, or some of them at least, are still living in the waters off southwestern California. No elephant seals have been heard of in this vicinity for many years. The nearest rookery is Guadalupe Island and it seems more natural to believe thet the specimens recently reported are escaped animals rather than ones that have left the herd at Guadalupe and wandered north.-JOHN ROWLEY, Los Angeles Museum, Los Angeles, California.

MUSKRATS IN CENTRAL EUROPE

In 1906 Princess Colloredo-Mannsfeld imported four pairs of muskrats (Fiber zibethicus) from America and turned them loose in Dobrisch, an estate southwest of Prague, Bohemia. These animals subsequently increased in such numbers that at present they have spread all over Bohemia, into Upper and Lower Austria and Moravia and also into Bavaria and Saxony, following the watercourses.

The muskrats have shown themselves to be very injurious, as they construct their burrows in the dams and embankments of the rivers and ponds, and thus, by undermining the banks they endanger the whole system of waterways, subjecting the surrounding fields to the danger of floods.

Very strict regulations have been issued, therefore, in all the countries invaded by the muskrat, to curtail its further spread, and it is generally forbidden under heavy fines to maintain the animals, breed them, or turn them loose. All persons, directly or indirectly interested, are required to report every appearance of muskrats to the authorities. Owing to his secretive habits of life, the muskrat of ten succeeds in remaining unnoticed for a considerable period in his new haunts.

The muskrat is inclined to be nocturnal, but in districts where he feels himself unnoticed he is to be seen during the day also. In general it has been observed that during overcast weather and dark nights the rats do not appear for days at a time, and rarely swim about when it is windy. The muskrat builds his summer-dwelling in the high banks or dams of water courses and ponds. This consists of a burrow from which a carefully concealed exit leads to the bank, often 10 to 15 feet away; other runways lead under the water level and to the bottom of the water. Piles of earth which have been removed from the ponds are also used.

The animals established in Europe breed twice or three times a year and produce 6 or 8 young at \& time. Thus an annual family of 18 to 24 young may be expected which sufficiently explains the phenomenal spreading of the species.

In winter the muskrats often abandon their burrows and build so called "winter-castles" in shallow places in the ponds. These consist of heaps of bitten off reeds, rushes or sedges, more or less mixed with mud. They have a diameter of 3 to 6 feet, project 2 to 3 feet above water level, and have no visible exits. These quarters contain a dry sleeping-place above water level and, connected with it, a burrow extending into the water. 